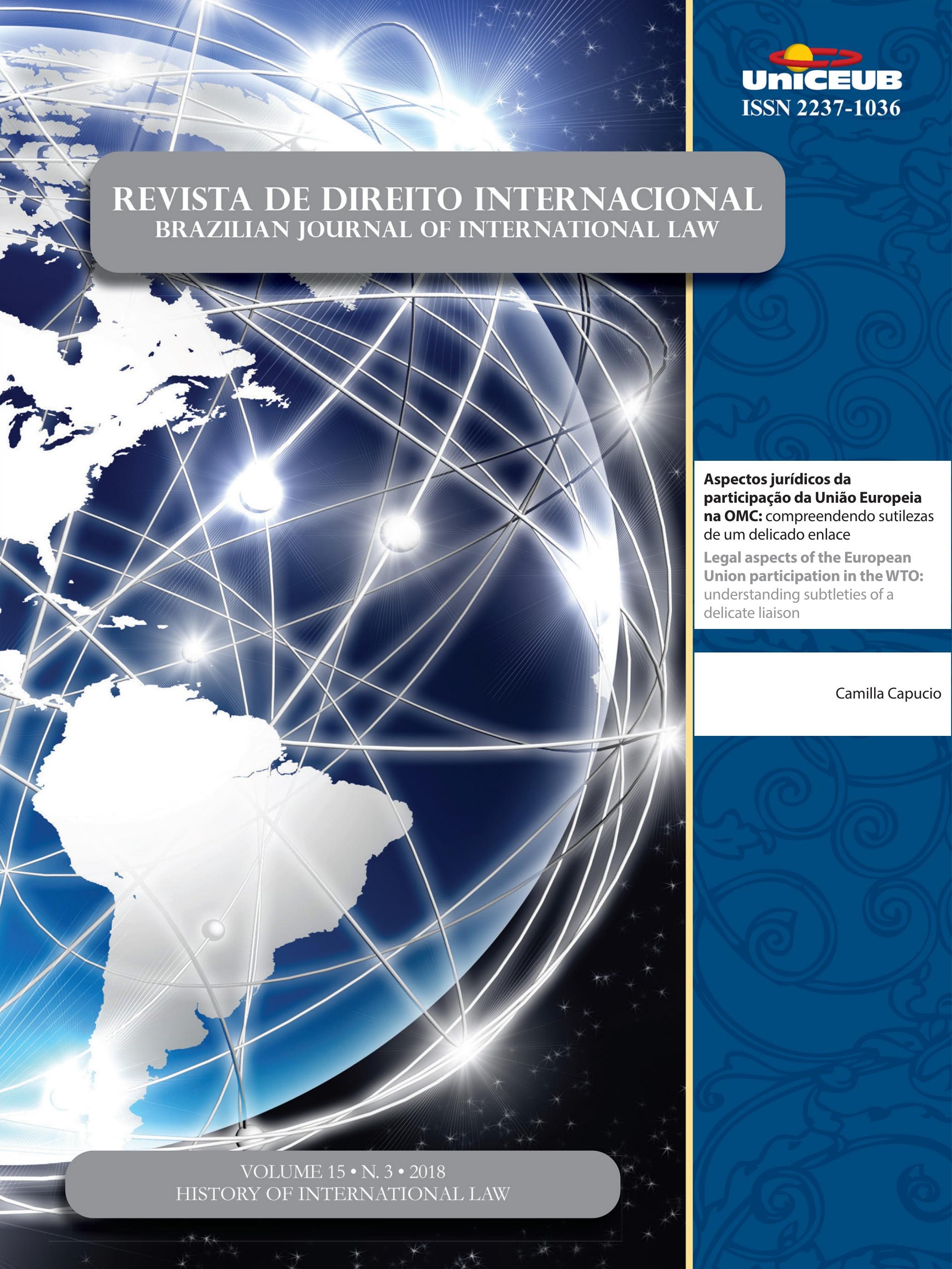




\section{Sumário}

I. Dossiê Especial: History of International Law ...................................1

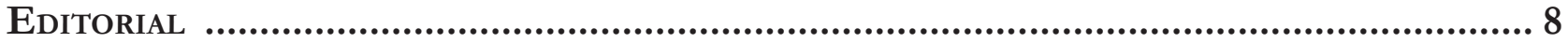

What does it mean to apply history in international law studies? ....................................................... 8

Arthur Roberto Capella Giannattasio

SuR LA NATURE DU Droit ISLAMIQUe............................................................................14

Hocine Benkheira

Islamic Shari’a Law, History and Modernity: Some Reflections .................................25 Suleiman A. Mourad

The (Un)practical Secularization Process: International Law and Religion as So-

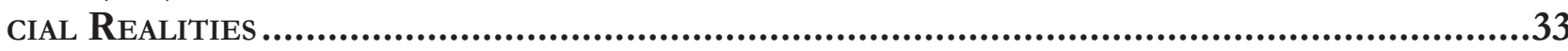

Douglas de Castro

BRAZILIAN LITERATURE ON INTERNATIONAL LAW DURING THE EMPIRE REGIME. OR THE DIFFUSION OF INTERNATIONAL LAW IN THE PERIPHERIES THROUGH APPROPRIATION AND ADAPTATION.

Airton Ribeiro da Silva Júnior

Natural, POSitivo, romano E Universal? INVESTigaÇão SObre O Direito das GENTES EM

Tomás de Aquino

Rafael Zelesco Barretto

II. Artigos sobre outros temas

VINCULAÇÃO DOS DIREITOS ECONÔMICOS, SOCIAIS E CULTURAIS: UMA DISCUSSÃO DO DESENVOLVImento humano com base no conceito de Amartya Sen sobre o mínimo existencial.....99

Natalia Mascarenhas Simões Bentes e Yasmim Salgado Santa Brígida

A NOVA LeI de MigraÇão E A PROTEÇão CONFERIDA AO APÁtrida: ALINHAMENTO BRASILEIRO AO PADRÃO INTERNACIONAL DE DIREITOS HUMANOS

Pedro Henrique de Faria Barbosa e Sylvio Loreto

E se o Supremo Tribunal Federal (STF) restabelecer a vigência da Convenção n. 158 
da Organização Internacional do Trabalho (OIT) na ordem Jurídica brasileira? SoBRE UMA POSSÍVEL REVIRAVOLTA, PELA VIA DO DIREITO INTERNACIONAL, DAS LEIS TRABALHISTAS BRASILEIRAS 138

Daniel Damasio Borges

JULGADOS DA CORTE INTERAMERICANA SOBRE CASOS BRASILEIROS E POLÍTICAS PÚBLICAS: REFLEXÕES ACERCA DE POSSÍVEIS INFLUIÇÕES 165

Rafael Osvaldo Machado Moura

CREATING BRIDGES BETWEEN INTERNATIONAL RELATIONS THEORY AND INTERNATIONAL HUMAN RIGHTS LAW: CONSTRUCTIVISM AND THE ROLE OF BRAZIL IN THE INTER-AMERICAN SYSTEM OF HUMAN RIGHTS 179

Ismael Francisco de Souza, Luciana Rocha Leme e Erick da Luz Scherf

Justiça de transição na Argentina e o Sistema Interamericano de Direitos Humanos: uMa ANÁlise do CASo Luis Muiña (“REgRa 2x1”) 199

Emilio Peluso Neder Meyer e Jessica Holl

A legalidade e legitimidade da INTERVEnÇão humanitÁria: UMA MEDIDA AINDA NECESSÁRIa.219 Natália Caye Batalha Boeira

O Acordo de Escazú E o ACESSo À INFORMaÇão AMbiental no Brasil. 252 Érica Bezerra Queiroz Ribeiro e Bruno Amaral Machado

Dos POVOS NATIVOS AO SURGIMENTO DOS MOVIMENTOS SOCIAIS: INFLUÊNCIAS DOS DISCURSOS JURÍDICOS, RELIGIOSOS E MÉDICOS PARA A CONSTRUÇÃO DO CONCEITO DE HOMOSSEXUALIDADE NO BRASIL .267 Bruno Rafael Silva Nogueira Barbosa e Robson Antão de Medeiros

Aspectos Jurídicos da PARTicipaÇão dA UNião Europeia NA OMC: COMPREENDENdo SUTILEZAS DE UM DELICADO ENLACE. 291

Camilla Capucio

Path to judicial activism? The use of "Relevant rules of international law" by the WTO Appellate Body

Mariana Clara de Andrade

LEVEZA E PESO NA MEDIAÇÃO COMERCIAL INTERNACIONAL: O CONTEÚDO JURÍDICO DO ACORDO CORPORATIVO MEDIADO E SUA INCORPORAÇÃo PELO DiREITO BRASILEIRO .324 Henrique Lenon Farias Guedes 
JURISDIÇÃO INTERNACIONAL E AS DIFICULDADES DE EXECUÇÃO DE SENTENÇAS INTERNACIONAIS NO BRASIL

Nevitton Vieira Souza

O DEVER DE COOPERAÇÃo NOS CONTRATOS DE VENDA INTERNACIONAL DE MERCADORIAS: PRESSUPOSTOS TEÓRICOS E REPERCUSSÕES PRÁTICAS DA CLÁUSULA GERAL DA BOA-FÉ OBJETIVA PARA A APLICAÇÃo DA CISG .358

Angelo Gamba Prata de Carvalho

A DiMENSÃo JURÍdiCA DO IMPERIALISMO NA (DES)ORDEM GLOBAL CAPITALISTA: UMA ANÁLISE COM BASE NA CRÍTICA MARXISTA AO DIREITO INTERNACIONAL E ÀS RELAÇÕES POLÍTICO-ECONÔMICAS DE DOMINAÇÃO E DEPENDÊNCIA.

Thomaz Delgado De David, Maria Beatriz Oliveira da Silva e Rosane Beatris Mariano da Rocha Barcellos Terra

A participaÇão de Brasil e Estados Unidos na formulação das regras multilaterais do

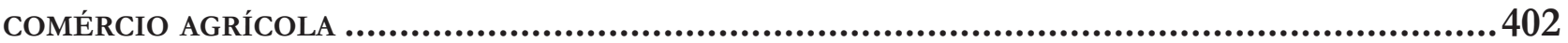

Vera Thorstensen, Vivian Daniele Rocha Gabriel e Alebe Linhares Mesquita

A galáxia lex e a construÇão de um Sistema jurídico transnacional ........................ 441

Eugênia Cristina Nilsen Ribeiro Barza e Jéssyka Maria Nunes Galvão

Has the Ability of Truth Commissions to Recommend Amnesty Been Effective in Enhancing Perpetrator Cooperation? 453 Jeremy Sarkin

A CONCEPTUAL PAPER ON THE POLICY-FRAMEWORK THAT MIRRORS THE DYNAMIC LINK BETWEEN Human Security, Social Protection and Safety Nets, and Food and Nutritional Security: The Case of the "Gulayan sa Paaralan Program", the Philippines.... 478 Renato Lagapa Base

INCENTIVISING SMALLHOLDER FARMER LIVELIHOODS AND CONSTRUCTING FOOD SECURITY THROUGH HOME-GROWN SCHOOL FEEDING: EVIDENCE FROM NORTHERN GHANA .491

Clement Mensah

Policy COHERENCE In THE IMPLEMENTATION OF THE 2030 AgENDA FOR SUSTAINABLE DEVELOpment: the Brazilian School Feeding Programme Case Study .506 Mariana Werlang Girardi 


\title{
Aspectos jurídicos da participação da União Europeia na OMC: compreendendo sutilezas de um delicado enlace*
}

\author{
Legal aspects of the European Union \\ participation in the WTO: understanding \\ subtleties of a delicate liaison
}

Camilla Capucio**

\section{Resumo}

O presente trabalho busca analisar a participação da União Europeia na Organização Mundial do Comércio, contextualizando as condições jurídicas de sua vinculação como membro em status próprio, bem como evidenciando as complexidades oriundas de sua participação no sistema de solução de controvérsias da OMC. Para alcançar tais objetivos, foram examinadas fontes primárias (tratados da União Europeia) e secundárias (jurisprudência do Tribunal de Justiça da União Europeia), revisitadas criticamente pela doutrina especializada. O trabalho parte de noções introdutórias, buscando abordar algumas imprecisões jurídicas que compõem o delicado arranjo que permite a participação da União Europeia como membro da OMC. O trabalho aborda um problema teórico pouco analisado, pois situa-se em tema de convergência entre diferentes áreas (Direito Internacional Econômico e Direito Comunitário ou da União Europeia), sendo assunto especialmente inovador na doutrina brasileira, e nisso consiste sua principal contribuição. Após a análise, aplicando a metodologia descrita, constatou-se que a definição dos limites entre as competências da União e dos Estados membros na participação na OMC e em seu sistema de solução de controvérsias pelo TJUE se deu com notável pragmatismo, desconsiderando institutos até então consagrados no direito comunitário. Com a preocupação de reforçar a inexistência de aplicabilidade direta das normas primárias e secundárias do Direito da OMC, o Tribunal teve em vista uma espécie de proteção de sua ordem comunitária em face de intervenções externas. Por fim, constatou-se que as instituições comunitárias têm buscado incrementar a transparência, accountability e legitimidade da participação da União Europeia na OMC, com recentes iniciativas de procedimentalização intracomunitária.

Palavras-chave: União Europeia. OMC. Solução de controvérsias. Sistema de solução de controvérsias da OMC.

** Doutora em Direito Internacional pela Faculdade de Direito da Universidade de São Paulo -USP. Mestre em Direito pela Faculdade de Direito da Universidade Federal de Minas Gerais - UFMG e bacharel em direito pela mesma universidade, com experiência de estudos realizados na Universitá di Bologna - UNIBO. Ex-bolsista do CNPq. Advogada e Consultora Jurídica. Professora do Centro Universitário UNA. Coordenadora da linha temática sobre o Mecanismo de Solução de Controvérsias da OMC, do Núcleo de Estudos em Tribunais Internacionais - NETIUSP. Email: ccapucio@usp.br. 


\section{Abstract}

This paper intends to analyze the participation of the European Union in the World Trade Organization, contextualizing the legal conditions of its membership as a member itself, as well as highlighting the complexities arising from its participation in the WTO dispute settlement system. In order to achieve these objectives, primary sources (European Union treaties) and secondary sources (jurisprudence of the Court of Justice of the European Union) have been consulted, revisited critically by the specialized doctrine. The work is based on introductory notions, seeking to address some legal imprecisions that constitutes the delicate arrangement that allows the participation of the European Union as a member of the WTO. This paper adress a theorethial problem that has not been frequently analyzed, as it is a topic of convergence between different areas (International Economic Law, Community Law or the Law of European Union), being a particularly innovative subject in Brazilian legal doctrine, what constitutes its main contribution. Applying the methodology described, the analysis reached the conclusion that in the definition of the limits between the competences of the Union and the Member States in the participation in the WTO and in its Dispute Settlement System the Court was remarkable pragmatic, disregarding hitherto established institutes in Community law. With an intention to reinforce the lack of direct applicability of the primary and secondary rules of WTO law, the Court sought to protect the community order from external intervention. Finally, it was found that the Community institutions have been sought to increase the transparency, accountability and legitimacy of the European Union's participation in the WTO, with recent initiatives of intra-Community proceduralisation.

Keywords: European Union. WTO. Disoute settlement. WTO Dispute Settlement System.

\section{INTRODUÇão}

A participação da União Europeia na OMC, e consequentemente no seu Sistema de Solução de Controvérsias, abarca uma série de peculiaridades decorrentes de sua natureza jurídica não estatal. Inicialmente, cumpre brevemente destacar que a estrutura jurídica que permite a participação da UE na OMC é ainda hoje um emaranhado de ambiguidades jurídicas, ${ }^{1}$ no que tange ao compartilhamento das competências entre a União e os seus Estados membros e no tocante aos efeitos do Direito da $\mathrm{OMC}^{2}$ na ordem jurídica comunitária. ${ }^{3}$

A conclusão da Ata de Marrakesh se deu na forma de um acordo misto, ${ }^{4,5}$ no qual os Estados membros aderiram juntamente à União — então denominada Comunidades Europeias - , em função da opinião consultiva 1/94 do Tribunal de Justiça da União Europeia (TJUE/ TJCE). ${ }^{6}$ Naquela oportunidade, o TJUE/TJCE ${ }^{7}$ consi-

1 Para uma visão geral desse "emaranhado". KUIJPER, Pieter J. The conclusion and implementation of the Uruguay Round Results by the European Community. European Journal of International Law, v. 6, p. 222-244, 1995; LEAL-ARCAS, Rafael. Polycephalous anatomy of the EC in the WTO: an analysis of law and practice. Florida Journal of International Law, v. 19, p. 569-670, 2007.; BRAND, Ronald A. Direct effect of international economic law in the United States and the European Union. Northwestern Journal of International Law \& Business, v. 17, n. 1, p. 556-608, 1996-1997.

2 Este trabalho adota a expressão "Direito da OMC" para designar o conjunto de normas primárias e secundárias do sistema multilateral de comércio, enquanto parte constitutiva do Direito Internacional Econômico. Para uma visão de recentes discussões acerca da OMC e de suas diversas temáticas na doutrina nacional, remete-se à consulta da edição especial da REVISTA DE DIREITO INTERNACIONAL, v. 11, n. 2, 2014. Disponível em: https://www.rdi.uniceub.br/rdi/issue/view/197. Acesso em: 11 dez. 2018.

3 Embora a literatura mais recente tenha debatido com frequência a "crise" da União Europeia, em especial a partir do Brexit - saída do Reino Unido da UE, é relevante destacar que tal conjuntura não desabona o significativo desenvolvimento normativo-institucional do ordenamento jurídico comunitário, com características ímpares como: primazia do direito comunitário, direta aplicabilidade, acesso ao sistema jurisdicional e aplicação de direitos e garantias supranacionais. Desse modo, não se abala a capacidade dessa ordem jurídica de oferecer modelos de mecanismos e instrumentos bem-sucedidos, especialmente no que tange à lógica diferenciada de relação entre o Direito Internacional (comunitário) e o direito interno dos Estados membros.

4 HELISKOSKI, Joni. Mixed agreements as a technique for organizing the international relations of the european community and its member states. Boston: Kluer Law International, 2001. BASTOS, Fernando Loureiro. Os acordos mistos em direito comunitário: contributo para a compreensão do seu fundamento jurídico. Lisboa: SPB II Editores, 1999.

5 Para uma reflexão sobre as consequências jurídicas da celebração dos Acordos da OMC como acordos mistos na divisão de responsabilidade, com base na Convenção de Viena sobre o Direito dos Tratados de 1986. STEINBERGER, Eva. The WTO treaty as a mixed agreement: problems with the EC's and the EC member states' membership of the WTO. European Journal of International Law, v. 17, n. 4, p. 837-862, 2006.

6 Opinion 1/94 (Rec.1994, p.I-5267), 15 nov. 1994.

7 Referimo-nos ao Tribunal de Justiça da União Europeia (TJUE) como o órgão jurisdicional principal da atual União Europeia. Sua configuração modificou-se com o passar do tempo, assim como sua nomenclatura, uma vez que era anteriormente designado Tribunal 
derou que a regra do single undertaking exigia a participação dos Estados membros em sua capacidade individual na OMC, uma vez que não havia competência comunitária exclusiva para abarcar todos os Acordos.

Tal competência exclusiva existia apenas para o Acordo GATT 1994, relativo ao comércio de bens, para o Acordo sobre Agricultura, para o Acordo de Medidas Sanitárias e Fitossanitárias e para o Acordo sobre Barreiras Técnicas ao Comércio, por força do então artigo 133 do Tratado da CE. ${ }^{8}$ No que se referia ao GATS, o Tribunal concluiu que alguns modos de fornecimento ("consumption abroad", "commercial presence" e "presence of natural persons") não estariam abarcados pela política comercial comunitária, envolvendo competência compartilhada com os Estados membros. De modo similar, em relação ao TRIPS, o Tribunal concluiu que havia competência compartilhada, uma vez que a regulamentação trazida pelo Regulamento do Conselho n. 3842/86 não configurava uma completa harmonização em nível comunitário. ${ }^{9}$

Embora tenha declarado, portanto, a necessidade de comprometimento em conjunto pelos Estados membros e pela então Comunidade para participação na arquitetura normativa da OMC, o Tribunal perdeu a oportunidade de esclarecer com precisão a relação entre a então Comunidade e os Estados membros nessa matéria, o que futuramente resultaria numa série de controvérsias sobre a divisão de responsabilidades entre os Estados e a União em relação a violações de regras multilaterais. ${ }^{10}$

Assim, o presente trabalho parte da necessidade de compreender esse delicado enlace que permite, a partir dessa série de relações entre institutos do Direito Comunitário ou da União Europeia ${ }^{11}$ e do Direito Interna-

de Justiça das Comunidades Europeias (TJCE). Não faremos diferenciação precisa entre eles, e pela compreensão de continuidade, nos referimos também por meio da sigla TJUE/TJCE.

8 Artigo 133 do Tratado que institui a CE, que por força do artigo 188-C do Tratado de Lisboa, passou a ser renumerado como o Artigo 207 do TFUE.

9 Para um estudo introdutório descritivo de nuances de peculiaridades da participação da UE na OMC. CAPUCIO, Camilla. A União Européia como sujeito de direito internacional: estudos sobre sua natureza jurídica e o Treaty Making Power Comunitário. Revista Eletrônica de Direito Internacional, v. 5, p. 34-68, 2009. Disponível em: http://www.cedin.com.br/revistaeletronica/volume5/. Acesso em: 20 ago. 2018.

10 TRACHTMAN, Joel P. Bananas, direct effect and compliance. European Journal of International Law, v. 10, n. 4, p. 655-678, 1999.

11 O presente trabalho adota os termos "Direito Comunitário" cional Econômico ${ }^{12}$ ora brevemente destacados, a participação da União Europeia como membro do Sistema Multilateral de Comércio - bem como as consequências jurídicas e ambiguidades de tal participação.

O trabalho se desenvolve, com base em três seções, que buscarão endereçar, a partir dessa breve apresentação do tema: (a) os efeitos jurídicos do Direito da OMC na ordem jurídica comunitária; (b) a governança interna à UE para tomada de decisão na $\mathrm{OMC}$ (c) e a procedimentalização da participação da UE na OMC.

\section{EfEITOS do Direito dA OMC NA ORDEM JURÍDICA COMUNITÁRIA E A JURISPRUDÊNCIA DO TJUE}

A opinião consultiva 1/94 endereçou, apenas, uma das diversas imprecisões iniciais no tocante às competências para integrar a OMC, deixando em aberto complexidades como a definição dos efeitos do Direito da OMC no ordenamento jurídico da União. Em face de preceito contido originariamente no Tratado de Roma - pelo qual tratados celebrados entre a Comunida-

e "Direito da União Europeia" como expressões intercambiáveis. Embora parte minoritária da doutrina adote postura "purista" nessa temática, vislumbrando significados que após a criação da UE as expresses indicariam objetos distintos, nos filiamos à corrente que vislumbra na União Europeia uma institucionalização evolutiva de um mesmo objeto: a ordem jurídica comunitária, construída com o intuito de estabelecer uma nova comunidade de direito, com características distintivas, enunciadas na jurisprudência clássica do TJCE. A esse respeito: "Na União Europeia, bloco econômico em regime de mercado comum e união monetária, vigora um direito específico e peculiar que é o Direito Comunitário, de caráter supranacional e dotado das seguintes características: aplicabilidade direta (vale dizer que a norma do bloco não necessita ser internalizada nos ordenamentos jurídicos dos Estados), primazia frente às normas nacionais (naqueles eventos em que, caso as normas nacionais conflitem com as normativas do bloco, sempre terão primazia as primeiras) e a uniformidade na interpretação e na aplicação das normativas". GOMES, Eduardo Biachi. Integração econômica no MERCOSUL: opiniões consultivas e a democratização no acesso ao tribunal permante de revisão. Revista de Direito Internacional, Brasília, v. 10, n. 1, p. 128-136, 2013. p. 131. Também partindo da mesma equivalência: DIZ, Jamile Bergamaschine Mata; JAEGER JÚNIOR, Augusto. Por uma teoria jurídica da integração regional: a inter-relação direito interno, direito internacional público e direito da integração. Revista de Direito Internacional, Brasília, v. 12, n. 2, p. 138-158, 2015.

12 BADIN, Michelle Ratton Sanchez; MOROSINI, Fabio Costa; OLIVEIRA, Inaê Siqueira de. Direito internacional econômico no Brasil: quem somos e o que fazemos?: evidências empíricas de 1994 a 2014. Revista de Direito Internacional, Brasília, v. 13, n. 1, p. 5-25, 2016. 
de e um ou mais de seus Estados membros, ou entre a Comunidade e uma Organização Internacional, seriam vinculantes para as instituições comunitárias - surgiram discussões acerca da aplicabilidade direta dos acordos internacionais concluídos pela Comunidade.

O TJUE/TJCE desenvolveu, contudo, uma cautelosa interpretação em sua jurisprudência acerca dos requisitos para a aplicabilidade direta dos acordos internacionais, como se verifica nos casos Haegemann, ${ }^{13}$ Bresciani, ${ }^{14}$ e Demirel. ${ }^{15}$

Contudo, em todas as oportunidades em que foi convocado para decidir sobre a aplicabilidade do GATT 1947, o Tribunal ponderou elementos de peculiaridade do Acordo para negar sua aplicabilidade direta e, portanto, sua exigibilidade judicial. Nos casos International Fruit Company, ${ }^{16}$ Schlüter-Lörrach, ${ }^{17}$ SIOT, ${ }^{18}$ Michelin Italiana (SAMI), ${ }^{19}$ e Bananas, ${ }^{20}$ o Tribunal negou aplicabilidade direta ao GATT 1947, afirmando a impossibilidade de invocar suas provisões para questionar a legalidade de atos comunitários, em razão do caráter "condicionado" e "flexivel" dos compromissos que esse Acordo estabelece.

13 No caso Haegeman, o Tribunal explicitou que: "[... an agreement concluded by the council under articles 228 and 238 of the eec treaty is, as far as concerns the community, an act of one of the institutions of the community the meaning of subparagraph (b) of the first paragraph of article 177. From the date it comes into force, its provisions form an integral part of community law." TJUE/TJCE. Haegemann v. Belgian State (Rec.1974, p.449), Case 181/73, 30 abr. 1974.

14 No caso Bresciani, o Tribunal concluiu que sendo uma obrigação decorrente do Tratado Internacional "[...] specific and not subject to any implied or express reservation on the part of the community, it is capable of conferring on those subject to community law the right to rely on it before the courts."TJUE/TJCE. Bresciani v. Amministrazione delle finanze dello Stato (Rec.1976, p.129), Case 87/75, 5 fev. 1976.

15 De modo similar, no caso Demirel foi explicitado que " $[. .$.$] a$ provision in an agreement concluded by the community with non-member countries must be regarded as being directly applicable when, regard being had to its wording and the purpose and nature of the agreement itself, the provision contains a clear and precise obligation which is not subject, in its implementation or effects, to the adoption of any subsequent measure."TJUE/TJCE. Demirel $v$. Stadt Schwäbisch Gmünd (Rec.1987, p.3719), Case 12/86, 30 out. 1987. 16 TJUE/TJCE. International Fruit Company and others v. Produktschap voor Groenten en Fruit (Rec.1972, p.1219), Case 21/72, 12 dez. 1972.

17 TJUE/TJCE. Scblüter v. Hauptzollamt Lörrach (Rec.1973, p.1135), Case 9/73, 24 out. 1973.

18 TJUE/TJCE. SIOT v. Ministero delle finanze (Rec.1983, p.731), Case 266/81, 16 mar. 1983.

19 TJUE/TJCE. Amministrazione delle finanze dello Stato v. SPI and SAMI (Rec.1983, p. 801), Case 267/81, 16 mar. 1983.

20 TJUE/TJCE. Germany v. Council (Rec.1994, p.I-4973), Case 280/93, 5 out. 1994.
Ao reconhecimento geral da não aplicabilidade do direito decorrente do GATTT 1947, o Tribunal reconheceu duas exceções restritas, nos casos Fediol ${ }^{1}$ e Nakajima. ${ }^{22}$ No primeiro caso, embora reafirmando que as regras do GATT não tinham efeito direto, o Tribunal aceitou uma ação judicial com base na violação de um Regulamento da Comissão que fazia referência expressa ao GATT 1947. No segundo caso, um Regulamento antidumping foi questionado com base nas regras do GAT'T 1947 e o Tribunal aceitou examinar sua legalidade, pois era uma medida tomada pela CE que intencionava implementar uma obrigação em particular.

Com a passagem do GATT 1947 para a OMC, houve profunda institucionalização e adensamento de juridicidade do sistema multilateral de comércio, por meio de sua arquitetura normativa e pelo seu Sistema de Solução de Controvérsias, que a princípio justificaria uma nova perspectiva sobre o tema. Assim, com a diminuição da condicionalidade e da flexibilidade das regras multilaterais houve expectativa de que a interpretação do Tribunal pudesse se modificar.

Contudo, quando o Tribunal foi chamado a se pronunciar no caso Portugal v. Council (149/96), declarou a negação da aplicabilidade direta também às regras da OMC, desconsiderando os ganhos em institucionalidade e juridicidade ocorridos com a passagem do GATT para a OMC. Embora a controvérsia tenha sido solucionada no âmbito da interpretação jurisdicional do Tribunal, a esse respeito já havia a resolução da Comissão da UE aprovando a Ata de Marrakesh que já explicitava a visão da Comissão de que os Acordos por si só não eram diretamente aplicáveis. ${ }^{23}$

No caso 149/96, o Tribunal não aceitou a invocação de regras da OMC por Portugal como base para questionar uma decisão do Conselho. ${ }^{24}$ Naquela oportunidade, o Tribunal destacou o caráter negocial das

21 TJUE/TJCE. Fédération de l'industrie de l'builerie de la CEE (Fediol) v. Commission (Rec.1989, p. 1-1781), Case C-70/87, 22 jun. 1989. 22 TJUE/TJCE. Nakajima All Precision Co. Ltd v. Council (Rec.1991, p. 1-2069), Case C-69/89, 7 maio 1991.

23 TJUE/TJCE. 94/800/EC: Council Decision (of 22 December 1994) concerning the conclusion on behalf of the European Community, as regards matters within its competence, of the agreements reached in the Uruguay Round multilateral negotiations (1986-1994), OJ L 336, 23.12.1994. p. 1-2. TJUE/TJCE. Commission of the European Communities, Proposal for a Council Decision Concerning the Conclusion of the Uruguay Round of Multilateral Trade Negotiations (1986-94) Com(94), 143 apr. 15, 1994.

24 TJUE/TJCE. Portugal v. Council (Rec.1999, p.I-8395), Case C-149/96, 23 nov. 1999. para. 41. 
obrigações e dos procedimentos do Sistema de Solução de Controvérsias da $\mathrm{OMC},{ }^{25}$ bem como o fato de que outros membros da OMC não consideravam as regras multilaterais vinculantes e diretamente aplicáveis às suas Cortes, ${ }^{26}$ para manter sua interpretação restritiva.

E, assim, segundo a interpretação do Tribunal no caso em comento, "segue-se que os acordos da OMC, interpretados à luz do seu objeto e finalidade, não fixam os meios jurídicos adequados para assegurar que estes sejam aplicados de boa-fé na ordem jurídica das partes contratantes. ${ }^{27}$

A posição do TJUE/TJCE enfrentou críticas dentre diversos doutrinadores, ${ }^{28,29,30}$ que, de maneira geral, o acusaram de sobrepesar elementos políticos no julgamento, em vez de realizar uma análise jurídica. ${ }^{31,32,33}$

25 TJUE/TJCE. Portugal v. Council (Rec.1999, p.I-8395), Case C-149/96, 23 nov. 1999. para. 42. "As regards, more particularly, the application of the WTO agreements in the Community legal order, it must be noted that, according to its preamble, the agreement establishing the WTO, including the annexes, is still founded, like GATT 1947, on the principle of negotiations with a view to 'entering into reciprocal and mutually advantageous arrangements' and is thus distinguished, from the viewpoint of the Community, from the agreements concluded between the Community and non-member countries which introduce a certain asymmetry of obligations, or create special relations of integration with the Community, such as the agreement which the Court was required to interpret in Kupferberg".

26 TJUE/TJCE. Portugal v. Council (Rec.1999, p.I-8395), Case C-149/96, 23 nov. 1999. para. 44. "Admittedly, the fact that the courts of one of the parties consider that some of the provisions of the agreement concluded by the Community are of direct application whereas the courts of the other party do not recognise such direct application is not in itself such as to constitute a lack of reciprocity in the implementation of the agreement (Kupferberg, paragraph 18)." 27 Tradução livre do original em língua inglesa: "[...] follows that the WTO agreements, interpreted in the light of their subject-matter and purpose, do not determine the appropriate legal means of ensuring that they are applied in good faith in the legal order of the contracting parties. "TJUE/TJCE. Portugal v. Council (Rec.1999, p.I-8395), Case C-149/96, 23 nov. 1999.

28 ANTONIADIS, Antonis. The European Union and WTO law: a nexus of reactive, coactive and proactive approaches. World Trade Review, v. 6, n. 1, p. 45-87, 2007.

29 ZONNEKEYN, Geert A. The latest on indirect efect of WTO Law in the legal order: the Nakajima case law misjudged? Journal of International Economic Law, p. 597-608, 2001.

30 EECKHOUT, Piet. Judicial enforcement of WTO Law in the European Union: some further reflections. Journal of International Economic Law, v. 5, p. 91-110, 2005. p. 107.

31 MENGOZZI, Paolo. Istituzione di Diritto Comunitario e Dell $\square$ Unione Europea. Padova: CEDAM, 2003. p. 367-369.

32 Como sustenta Rafael Leal-Arcas: "If the ECJ wants to maintain its doctrine that the GATT does not meet the direct effect test and extends it to other WTO Agreements, it will need to devise standards, other than those it has used until now, to deny direct effect to the GATT and WTO Agreements." LEAL-ARCAS, Rafael. Polycephalous anatomy of the EC in the WTO: an analysis of law and practice. Flórida Journal of International Law, v. 19, p. 569-670, 2007. p. 209.

33 Em posição contrária, Cf: "[... Tit should be noted that the main conclusion reached by the Court of Justice makes perfect sense. The WTO is a global intergovernmental endeavor, with an emphasis on a balance of conces-
Embora constitua um precedente relevante, que até atualmente embasa decisões do TJUE/TJCE nessa temática, a doutrina enfatiza que, no caso Portugal, os Acordos da OMC foram alegados pelo demandante como um parâmetro para questionar a legalidade de medidas comunitárias. Situação consideravelmente distinta seria aquela na qual o Tribunal tem à sua frente uma decisão do Sistema de Solução de Controvérsias da OMC, que deve ser considerada - apesar de certamente conter suas peculiaridades — — ${ }^{34}$ como uma decisão jurídica vinculante de um órgão adjudicatório internacional. ${ }^{35}$

Desde a opinião no caso Atlanta, ${ }^{36}$ o TJUE/TJCE teria perdido preciosas oportunidades de realizar essa inevitável diferenciação, tornando sua jurisprudência "confusa e desencorajadora" nessa seara. ${ }^{37}$ No caso Biret, ${ }^{38}$ embora tenha destacado que o Tribunal de primeira instância deveria ter diferenciado em sua análise, o precedente contido no caso Portugal da situação na qual um relatório adotado pelo Órgão de Solução de Controvérsias (OSC) $)^{39}$ não foi implementado pela UE, o Tribunal evitou adentrar na

sions or, to quote the Preamble of the Marrakesh Agreement, 'reciprocal and mutually advantageous arrangements'. Individual companies are not granted any direct right to a particular reduction of tariffs or other barriers to trade. [...] None of the major trading powers accord direct effect to the WTO Agreements in their internal legal orders." ROSAS, Allan. Implementation and enforcement of WTO dispute settlement findings: an EU perspective. Journal of International Economic Law, v. 4, p. 131-144, 2001. p. 140.

34 Acerca das especifidades das decisões do SSC da OMC, e a visão de que as mesmas não lhe retiram a natureza de decisão adjudicatória internacional. CAPUCIO, Camila. A natureza jurídica do Sistema de Solução de Controvérsias da OMC e de suas decisões: solucionando um imbróglio. Revista de Direito Internacional, Brasília, v. 14, n. 1, p. 315-340, 2017.

35 MENGOZZI, Paolo. Istituqione di Diritto Comunitario e Dell Unione Europea. Padova: CEDAM, 2003. p. 367-369.

36 TJUE/TJCE. Opinion of $M r$ Advocate General Mischo delivered on 6 May 1999. Atlanta AG and others v Commission of the European Communities and Council of the European Union (Rec.1999, p.I06983), Case C-104/97, 14 out. 1999. Foi a primeira situação na qual o tribunal foi chamado para expressar sua posição sobre o status de um Relatório adotado pelo Órgão de Solução de Controvérsias no ordenamento jurídico comunitário. ZONNEKEYN, Geert A. The legal status of WTO panel reports in the EC legal order: Some reflections on the opinion of advocate general Mischo in the Atlanta case. Journal of International Economic Law, v. 2, p. 713-722, 1999.

37 ERRICO, John. The WTO in the EU: Unwinding the Knot. Cornell International Law Journal, v. 44, p. 179-208, 2011.

38 TJUE/TJCE. Itablissements Biret et Cie SAv. Council (Rec.2003, p. I-10565), Case C-94/02, 30 set. 2003.

39 Sobre o desenho institucional que faz com que as decisões do OSC sejam, na realidade, decisões adjudicatórias internacionais, emanadas pelo OSC como integrante do Sistema de Solução de Controvérsias da OMC. CAPUCIO, Camila. A natureza jurídica do Sistema de Solução de Controvérsias da OMC e de suas decisões: solucionando um imbróglio. Revista de Direito Internacional, Brasília, v. 14, n. 1, p. 315-340, 2017. 
análise da controvérsia, reconhecendo que o demandante não poderia ter sofrido danos em função de elementos factuais do caso, ${ }^{40}$ esquivando-se de avaliar as consequências jurídicas da diferenciação do precedente.

No referido caso, o Advogado Geral reconheceu que a finalidade última do direito da OMC é a proteção dos indivíduos e que, portanto, as decisões do Sistema de Solução de Controvérsias deveriam poder ser invocadas pelas partes nos órgãos jurisdicionais comunitários. ${ }^{41}$ Embora tenha restado sem efeitos práticos, referida posição é valiosa ao explicitar que a invocabilidade direta de tais decisões não se apresenta como uma visão utópica ou destituída de fundamentação. ${ }^{42}$

Com base nesse caso, parte da doutrina interpreta que o TJUE/TJCE teria deixado a porta aberta para o reconhecimento de uma obrigação da UE consubstanciada nos relatórios adotados pelo OSC, e uma consequente responsabilidade em caso de não implementação das decisões do Sistema de Solução de Controvérsias da OMC. ${ }^{43,44,45}$

40 O fato de que o prazo para a implementação da decisão do OSC se esgoatava em 1999, e a empresa Biret foi objeto de liquidação judicial em 1995.

41 "It seems unfair to deny a citizen a right to claim damages where the Community legislature, by failing to act, maintains a state of affairs that is contrary to WTO law more than four years after the expiry of the period allowed to comply [...] and continues unlanfully to reduce the citizen's fundamental rights." Opinion of Advocate General Alber. TJUE/TJCE. Itablissements Biret et Cie SA v. Council (Rec.2003, p. I-10565), Case C-94/02, 30 set. 2003.

42 Para uma construção doutrinária sólida a este respeito, remetese à rica produção do prof. Ernst-Ulrich Petersmann. PETERSMANN, Ernst-Ulrich. From the hobbesian international law of coexistence to modern integration law: the WTO Dispute Settlement System. Journal of International Economic Law, v. 1, n. 2, p. 175-198, 1998; PETERSMANN, Ernst-Ulrich. How to constitutionalize international law and foreign policy for the benefit of civil society? Michigan Journal of International Law, v. 20, p. 1-30, 1998; PETERSMANN, Ernst-Ulrich. Human rights, international economic law and constitutional justice: a rejoinder. European Journal of International Law, v. 19, n. 5, p. 955-960, 2008; PETERSMANN, Ernst-Ulrich. Multilevel governance problems of the world trading system beyond the WTO Conference at Bali 2013. Journal of International Economic Law, v. 17, p. 233-270, 2014; PETERSMANN, Ernst-Ulrich. Multilevel judicial governance as guardian of the constitutional unity of international economic law. Loyola of Los Angeles International and Comparative Law Review, v. 30, n. 3, p. 367-418, 2008.

43 ALEMANNO, Alberto. Judicial enforcement of the WTO hormones ruling within the european community: toward ec liability for the non-implementation of WTO Dispute Settlement Decisions. Harvard International Law Journal, v. 45, p. 547-562, 2004.

44 ZONNEKEYN, Geert A. EC Liability for the Non-Implementation of WTO Dispute Settlement Decisions - Advocate General Alber Proposes a 'Copernican Innovation' in the Case Law of the ECJ. Journal of International Economic Law, v. 6, p. 761-769, 2003. 45 O princípio enunciado no caso Nakajima, como uma das ex-
Contudo, nos anos seguintes a esse caso, observou-se uma recrudescência da perspectiva expressa no precedente Portugal, ${ }^{46}$ com a rejeição das demandas nos casos IKE $A,{ }^{47}$ Leon Van Parys ${ }^{48}$ e Chiquita. ${ }^{49}$ Por fim, nos casos FIAMM ${ }^{50}$ o TJUE/TJCE rejeitou, repetidamente, a possibilidade de demandas com base em violação do Direito da OMC ou decisões do OSC sustentadas no artigo 340(2) do Tratado sobre o Funcionamento da União Europeia (TFUE). $.^{51},{ }^{52}$

A posição de não aplicabilidade direta das regras multilaterais e das decisões do Sistema de Solução de

ceções à não aplicabilidade, e retomado no caso Portugal poderia ser um pilar para este reconhecimento: "The principle of implementation clearly offers nice opportunities for communication between the vessels of $E U$ and WTO law, and between judicial operators of both systems. It would be particularly useful if it were applied, not only in straightforward cases of EC acts expressing to implement parts or provisions of WTO law, but also in the more politically charged context of implementation of WTO dispute rulings [...]”. EECKHOUT, Piet. Judicial enforcement of WTO Law in the European Union: some further reflections. Journal of International Economic Law, v. 5, p. 91-110, 2005. p. 109.

46 MEY, Delphine de. The effect of WTO Dispute Settlement Rulings in the EC Legal Order: Reviewing Van Parys v Belgische Interventie-en Restitutiebureau (C-377/02). German Law Journal, v. 6, p. 1025-1032, 2005; EGLI, Patricia. European Community-EC compliance with rulings of WTO Dispute Settlement Body in Bananas dispute- effect of WTO agreements and dispute settlement rulings in EC law-standing to challenge EC legislation as inconsistent with WTO agreements and rulings. American Journal of International Law, v. 100, p. 449-454, 2006. ERRICO, John. The WTO in the EU: Unwinding the Knot. Cornell International Law Journal, v. 44, p. 179-208, 2011.

47 Ikea Wholesale Ltd v. Comm'rs of Customs \& Excise (Rec.2007, p. 1-7723), Case C-351/04, 27 set. 2007.

48 TJUE/TJCE. Lon Van Parys NV v. Belgisch Interventie-en Restitutiebureau (BIRB) (Rec. 2005, p. 1-1465), Case C-377/02, 1 mar. 2005.

49 TJUE/TJCE. Chiquita Brands International, Inc. and Others v. Commission (Rec.2005, p. 11-315), Case T-19/01, 3 fev. 2005.

50 TJUE/TJCE. Fabbrica Italiana Accumulatori Motocarri Montecchio SpA v. Council (Rec.2008, p. 1-6513, 23-24, 30), Joined Cases C120/06P \& C-121/06P, 9 set. 2008.

51 O dispositivo citado correspondia ao artigo 288 do Tratado CE, convertido em atual artigo 340 para 2 na atual versão do Tratado sobre o Funcionamento da União europeia, como modificado pelo Tratado de Lisboa: "Em matéria de responsabilidade extracontratual, a União deve indemnizar, de acordo com os princípios gerais comuns aos direitos dos Estados-Membros, os danos causados pelas suas instituições ou pelos seus agentes no exercício das suas funções."

52 Assim, explicita Antonello Tancredi: "The main critique moved towards the Court's reasoning is that by misinterpreting the DSU provisions the ECJ has reached the incorrect conclusion that compensation and toleration of retaliation are suitable, albeit temporary, alternatives to full and immediate compliance. In other words, the ECJ seems to imply that compliance is negotiable, if provisionally, in the WTO." TANCREDI, Antonello. EC Practice in the WTO: how wide is the 'scope for manoeuvre'? European Journal of International Law, v. 15, n. 5, p. 933-961, 2004. p. 944. 
Controvérsias da OMC parece consagrar uma posição pragmática do Tribunal, tendo em vista uma indesejabilidade do reconhecimento dessas decisões como vinculantes às instituições comunitárias. A propósito, Mark Pollack argumenta sobre uma novíssima ideia de "soberania" da União Europeia no Direito Internacional, por meio da qual a UE tornou-se protetora de sua ordem comunitária em face de intervenções externas, em aproximação à postura norte-americana das relações internacionais. ${ }^{53}$

Adicionalmente, cumpre destacar que a jurisprudência do TJUE/TJCE é farta em conceitos e perspectivas que poderiam embasar a posição inversa da adotada nessa temática sensível. ${ }^{54}$ Nesse sentido vale destacar que, na Opinião 1/91, o Tribunal reconheceu que a Comunidade poderia se submeter a um órgão adjudicatório internacional, sob certas circunstâncias, e que suas decisões seriam vinculantes e cogentes às instituições comunitárias:

Quando, todavia, um acordo internacional estabelece o seu próprio sistema de tribunais, incluindo um tribunal competente para dirimir litígios entre as partes contratantes do acordo e, como resultado, para interpretar as suas disposições, as decisões do tribunal serão vinculativas às instituições comunitárias, incluindo o Tribunal de Justiça. Essas decisões também serão obrigatórias no caso de o Tribunal de Justiça ser chamado a pronunciar-se, por meio de decisão preliminar ou em uma ação direta, sobre a interpretação do acordo internacional, na medida em que o acordo é parte integrante de da ordem jurídica comunitária.

Um acordo internacional que preveja tal sistema jurisdicional é, em princípio, compatível com o direito comunitário. A competência da Comunidade no domínio das relações internacionais e sua capacidade para celebrar acordos internacionais necessariamente implica o poder de submeter-se às decisões de um tribunal que seja criado ou designado por um acordo desse tipo no que diz respeito à interpretação e aplicação das suas disposições. ${ }^{55}$

53 POLLACK, Mark A. The new, new sovereigntism or how the Europe Union became disenchanted with international law and defiantly protective of its domestic legal order. 2017. Disponível em: http://dx.doi.org/10.2139/ ssrn.2956738. Acesso em: 09 set. 2018.

54 Em sentido correlato: "[...] The ECJ is the direct effect court par excellence, and by refusing to extend the direct effect doctrine to WTO law, it is refusing to impose duties upon itself analogous to those which it has imposed on courts and tribunals in the EC Member States. By developing the notion of direct effect, the ECJ has urged domestic courts to give effect to EC law, but it is itself refusing to give effect to WTO law [...]” EECKHOUT, Piet. Judicial enforcement of WTO Law in the European Union: some further reflections. Journal of International Economic Law, v. 5, p. 91110, 2005. p. 98.

55 Tradução livre do original em Língua Inglesa: "Where, however,
É relevante destacar que, embora a aplicabilidade direta pudesse ser tecnicamente justificada, conforme se buscou destacar, a posição do tribunal espelha a prática de outros membros da OMC. Especificamente, o fato de outros ordenamentos jurídicos não conferirem aplicabilidade e invocabilidade direta foi um dos argumentos nos quais se embasou o TJUE/TJCE para negar esses efeitos, e essa argumentação tende a ser utilizada por outros membros. ${ }^{56}$ Desse modo, constrói-se uma lógica de certo modo tautológica e que leva à tendência de recrudescimento da limitação da possibilidade de exercício de direitos pelos indivíduos com base no Direito da OMC em diversos ordenamentos.

No que se refere, especificamente, ao Sistema de Solução de Controvérsias da OMC, reconhece-se que a UE/CE mantém o multilateralismo como elemento central da projeção internacional de sua política comercial, buscando promover uma implementação "mais expedita" das decisões do Sistema de Solução de Controvérsias da OMC. Isto pois o multilateralismo econômico traduzido pela dimensão jurídica da OMC seria base de legitimidade e fortalecimento de sua própria colocação no comércio internacional. ${ }^{57}$

an international agreement provides for its own system of courts, including a court with jurisdiction to settle disputes between the Contracting Parties to the agreement, and, as a result, to interpret its provisions, the decisions of that court will be binding on the Community institutions, including the Court of Justice. Those decisions will also be binding in the event that the Court of Justice is called upon to rule, by way of preliminary ruling or in a direct action, on the interpretation of the international agreement, in so far as that agreement is an integral part of the Community legal order. An international agreement providing for such a system of courts is in principle compatible with Community law. The Community's competence in the field of international relations and its capacity to conclude international agreements necessarily entails the power to submit to the decisions of a court which is created or designated by such an agreement as regards the interpretation and application of its provisions." TJUE/TJCE. Opinion 1/91, Draft agreement relating to the creation of the European Economic Area (Rec. 1991, p. 1-6079), 14 dez. 1991. para. 39-40. 56 TJUE/TJCE. Portugal v. Council (Rec.1999, p.I-8395), Case C-149/96, 23 nov. 1999. para. 44. "Admittedly, the fact that the courts of one of the parties consider that some of the provisions of the agreement concluded by the Community are of direct application whereas the courts of the other party do not recognise such direct application is not in itself such as to constitute a lack of reciprocity in the implementation of the agreement (Kupferberg, paragraph 18)."

57 Nesse sentido se posiciona Carlos Cozendey: "Ao mesmo tempo, por não dispor de coesão interna similar a um Estado, a Comunidade Europeia (e também a União Europeia no seu alcance mais amplo) utiliza melhor seus fatores de poder num ambiente regulado por regras explicitas do que num cenário onde prevaleçam os elementos anárquicos do sistema internacional. Na União Europeia, o sistema internacional e o papel que nele possam representar os países que a constituem são uma justificativa de sua própria existên- 
Por outro lado, esse emaranhado de imprecisões jurídicas, como brevemente destacamos, às vezes causa dificuldades em temas como a implementação das decisões e a distribuição de competências e responsabilidades entre os Estados membros e a União.

Pode-se mencionar, por exemplo, a controvérsia European Communities - Customs Classification of Certain Computer Equipment, ${ }^{58}$ na qual os EUA entenderam que a UE e os seus Estados membros Irlanda e Reino Unido seriam responsáveis pela violação de disposições do GATT 1994, requisitando a formação de três painéis diversos para analisar a questão.

$\mathrm{Na}$ oportunidade, a UE tratou de firmar um acordo com os EUA, garantindo que somente contra ela seria a demanda. Referido caso explicitou o interesse da UE em não permitir interferências externas - sejam elas do SSC ou dos demais membros da OMC — na delimitação de competências e responsabilidades entre a UE e seus Estados membros, questões que o próprio Painel do caso evitou adentrar. ${ }^{59}$

\section{Aspectos da governança ComUnitária PARA TOMADA DE DECISÃO NA OMC}

É relevante, também, mencionar que a própria operacionalização da participação da UE na OMC é temática complexa e pouco transparente na relação entre as instituições comunitárias. Se formalmente a UE e todos os seus Estados são membros da OMC em seu status individual, na prática o bloco personifica um ator único nas negociações multilaterais e no Sistema de Solução de Controvérsias, ${ }^{60}$ como se evidencia no caso supracitado.

cia." COZENDEY, Carlos Márcio Bicalho. O Sistema de Solução de Controvérsias da OMC: para além dos contenciosos, a política externa. Disponível em: http://www.itamaraty.gov.br/temas/temas-multilaterais/copy_of_desenvolvimento-comercio-e-financas/organizacaomundial-do-comercio/solucao-de-controversias/cgc/artigo-cozendey. Acesso em: 15 dez. 2017. p. 16.

58 WORLD TRADE ORGANIZATION. Apellate body report, european communities: customs classification of certain computer equipment. WT/DS62/AB/R, WT/DS67/AB/R, WT/DS68/AB/R, 05 jun. 1998.

59 CAPUCIO, Camilla. O regionalismo e o comércio internacional. 2. ed. Belo Horizonte: Arraes Editores, 2017. CAPUCIO, Camilla. O status jurídico da União Européia como membro da OMC: estudo sobre os acordos mistos no direito comunitário. In: MENEZES, Wagner. Estudos de Direito Internacional. Curitiba: Juruá, 2009. p. 135-146. 60 SERDAREVIC, Asja. European Union and its member states as a collective actor in WTO decision-making process. ACES Cases, n. 2010.3.
O desenvolvimento da política comercial comum fica a cargo da Comissão, que pela complexidade de sua tarefa necessitou desenvolver instrumentos e procedimentos para a sua realização, como brevemente abordaremos. A tomada de decisão pela Comissão na esfera da OMC é criticada por seus reduzidos níveis de transparência, legitimidade e accountability, princípios basilares do direito comunitário. ${ }^{61}$

Houve, contudo, um avanço significativo na inclusão de competências ao parlamento europeu relacionadas à definição da política comercial comum, uma vez que, na redação original do então artigo 133 do Tratado que institui a CE ${ }^{62}$, o parlamento ficava de fora da tomada de decisão nessa matéria, alterada pelo Tratado de Lisboa. ${ }^{63}$

Disponível em: http://aei.pitt.edu/59173/1/ACES_Case_Serdarevic_2010.pdf. Acesso em: 05 mar. 2018.

61 SERDAREVIC, Asja. European Union and its member states as a collective actor in WTO decision-making process. ACES Cases, n. 2010.3. Disponível em: http://aei.pitt.edu/59173/1/ACES_Case_Serdarevic_2010.pdf. Acesso em: 05 mar. 2018. p. 1.

62 Artigo 133 constante na Redação do Tratado que institui a CE: "1. A política comercial comum assenta em princípios uniformes, designadamente no que diz respeito às modificações pautais, à celebração de acordos pautais e comerciais, à uniformização das medidas de liberalização, à política de exportação, bem como às medidas de defesa comercial, tais como as medidas a tomar em caso de dumping e de subsídios. 2 . Tendo em vista a execução desta política comercial comum, a Comissão submete propostas ao Conselho. 3. Quando devam ser negociados acordos com um ou mais Estados ou organizações interna- cionais, a Comissão apresenta, para o efeito, recomendações ao Conselho, que a autoriza a encetar as negociações necessárias. Cabe ao Conselho e à Comissão assegurar que os acordos negociados sejam compatíveis com as políticas e normas internas da Comunidade. As negociações são conduzidas pela Comissão, em consulta com um comité especial designado pelo Conselho para a assistir nessas funções e no âmbito das directrizes que o Conselho lhe possa endereçar. A Comissão apresenta regularmente ao comité especial um relatório sobre a situação das negociações. [...]"

63 Nova redação deste artigo, que por força do artigo 188-C do Tratado de Lisboa, passou a ser renumerado como o Artigo 207 do TFUE: "1. A política comercial comum assenta em princípios uniformes, designadamente no que diz respeito às modificações pautais, à celebração de acordos pautais e comerciais sobre comércio de mercadorias e serviços, e aos aspectos comerciais da propriedade intelectual, ao investimento estrangeiro directo, à uniformização das medidas de liberalização, à política de exportação, bem como às medidas de defesa comercial, tais como as medidas a tomar em caso de dumping e de subsídios. A política comercial comum é conduzida de acordo com os princípios e objectivos da acção externa da União. 2. O Parlamento Europeu e o Conselho, por meio de regulamentos adoptados de acordo com o processo legislativo ordinário, estabelecem as medidas que definem o quadro em que é executada a política comercial comum. 3. Quando devam ser negociados e celebrados acordos com um ou mais países terceiros ou organizações internacionais, é aplicável o artigo 218.o, sob reserva das disposições específicas do presente artigo. Para o efeito, a Comissão apresenta recomendações ao Conselho, que a autoriza a encetar as negociações 
No que tange, especificamente, ao gerenciamento da participação da UE no Sistema de Solução de Controvérsias da OMC, a Comissão desempenha um papel central. Dois órgãos da estrutura interna da Comissão são relevantes para o desempenho deste papel: o $D i$ rectorate-General for Trade (DG Trade, Diretório Geral de Comércio) e o Legal Service. ${ }^{64}$

\section{Procedimentalizando a participação na OMC: DESAFIOS E PERSPECTIVAS}

Existem dois procedimentos para o estabelecimento de uma disputa no Sistema de Solução de Controvérsias da OMC pela União Europeia. ${ }^{65} \mathrm{O}$ primeiro procedimento, embasado no artigo 207 do TFEU, ${ }^{66}$ mas de caráter informal e não escrito, permite que partes interessadas - do setor privado ou os próprios Estados membros - apresentem requerimento à Comissão para o estabelecimento de uma disputa no Sistema de Solução de Controvérsias da OMC. ${ }^{67}$

necessárias. Cabe ao Conselho e à Comissão assegurar que os acordos negociados sejam compatíveis com as políticas e normas internas da União. As negociações são conduzidas pela Comissão, em consulta com um comité especial designado pelo Conselho para a assistir nessas funções e no âmbito das directrizes que o Conselho lhe possa endereçar. A Comissão apresenta regularmente ao comité especial e ao Parlamento Europeu um relatório sobre a situação das negociações [...]"

64 Segundo a autora: "DG Trade is responsible for the political aspects of WTO dispute settlements, while the Legal Service deals with the legal aspects. $D G$ Trade decides over the initiation of disputes and requesting consultations with third parties, while the Legal Service is responsible for arguing the EU's case before the Panel and the Appellate Body of the WTO. The two DGs are mutually dependent on each other, since the Legal Service relies on the investigations and reports of DG Trade for obtaining facts important for a case, and DG Trade depends on the Legal Service for a successful outcome." SERDAREVIC, Asja. European Union and its member states as a collective actor in WTO decision-making process. ACES Cases, n. 2010.3. Disponível em: http://aei.pitt.edu/59173/1/ACES_Case_Serdarevic_2010. pdf. Acesso em: 05 mar. 2018. p. 8.

65 Para uma comparação entre ambos os caminhos, sob a perspectiva de seu uso prático, e das vantagens e desvantagens. SHAFFER, Gregory C. Is the EC moving towards a U.S. Partnership Model? In: SHAFFER, Gregory C. Defending interests: public-private partnerships in WTO litigation. Washington: Brooking Institutions Press, 2003. p. 65-101.

66 Artigo 133 do Tratado que institui a CE, que por força do artigo 188-C do Tratado de Lisboa, passou a ser renumerado como o Artigo 207 do TFUE.

67 Especificamente sobre o iter deste pedido, a autora descreve: "The usual procedure is that officials in DG Trade first examine and scrutinize the complaint in close cooperation with lawyers of the WTO and International Trade Team in the Commission's Legal Service. The issue is then discussed in the Trade Policy Committee before the Commission takes a final decision whether
O segundo caminho é embasado no Regulamento de Barreiras ao Comércio (Trade Barriers Regulation - TBR, Regulamento da Comissão n. 3286/94), ${ }^{68}$ que também permite que partes interessadas e Estados membros ingressem com requerimento à Comissão para investigação de barreiras ao comércio que lhe sejam prejudiciais.

Nesse procedimento, o Conselho da UE e os Estados membros podem atuar, por meio de um Comitê (advisory comitte), havendo, inclusive, a possibilidade de adoção de medidas retaliatórias pelo Conselho. ${ }^{69}$

Os processos de decisão relativos aos acordos comerciais internacionais se embasam no então artigo 133 do Tratado da $\mathrm{CE}^{70}$ e, por isso, o grupo de agentes nacionais com experiência e conhecimento em comércio internacional que representa o Conselho na temática da OMC é conhecido como o "Comitê 133". Sua composição,

to launch a WTO dispute, as sometimes a final opinion of the Committee is requested. 55 Furthermore, the Member States are informed about the developments in the dispute settlement proceedings during the Trade Policy Committee's meetings and the INTA committee is also briefed on the progress." SERDAREVIC, Asja. European Union and its member states as a collective actor in WTO decision-making process. ACES Cases, n. 2010.3. Disponível em: http://aei.pitt.edu/59173/1/ACES_Case_Serdarevic_2010. pdf. Acesso em: 05 mar. 2018. p. 11.

68 Council Regulation EC N. 3286/94 of 22 December 1994 laying down Community procedures in the field of the common commercial policy in order to ensure the exercise of the Community's rights under international trade rules, in particular those established under the auspices of the World Trade Organization. Official Journal L 349, 31 dez. 1994. p. 0071 - 0078.

69 Segundo o autor, foram também editados mecanismos semelhantes específicos para antidumping e subsídios: "[...] allows trade operators' complaints to be channelled through an administrative mechanism that, at any rate, ascribes mainly to the EC Commission the choice to either bring a complaint before the WTO supervisory organs or to terminate/ suspend the investigation, or alternatively to seek an agreed solution. Therefore, the TBR - at least partly - seems to share the function and the nature of the traditional diplomatic protection remedy provided for by general international law. TBRlike twin mechanisms have also been set up in the field of anti-dumping and for subsidized imports.". TANCREDI, Antonello. EC Practice in the WTO: how wide is the 'scope for manoeuvre'? European Journal of International Law, v. 15, n. 5, p. 933-961, 2004. p. 240.

70 Artigo 133 do Tratado que institui a CE, que por força do artigo 188-C do Tratado de Lisboa, passou a ser renumerado como o Artigo 207 do TFUE.

71 Assim destaca um relatório do World Wide Fund For Nature: "The Committee has no set numbers of participants and there can be around 50 people at its meetings. It operates at two main levels: - Deputy level: 3-4 national trade officials from each member state: Commerce or Trade Counsellors from the Permanent Representations in Brussels, plus 2-3 trade experts from the national capitals who meet on a Friday - Full member level or "top configuration": a monthly Friday meeting of national Trade Directors-General from member states, plus supporting officials. In addition, other meetings of national experts examine specific issues on behalf of the 133 Committee where specialist discussion is needed." WORLD WIDE FUND FOR NATURE. A league of gentlemen: who really runs EU trade decision-making? nov. 2003. Disponível em: 
operacionalização, ${ }^{72},{ }^{73}$ mandato ${ }^{74}$ e controle ${ }^{75},{ }^{76}$ são de de-

http: / $/$ www.google.com.br/url? $\mathrm{sa}=\mathrm{t} \& \mathrm{rct}=\mathrm{j} \& \mathrm{q}=\&$ esrc $=\mathrm{s} \&$ source $=\mathrm{w}$ eb\&cd $=1 \& v e d=0 C C 8 Q F j A A$ Acesso em: 6 mar. 2018. p. 8 .

72 Sobre sua operacionalização, o relatório destaca: "The 133 Committee thus has the main responsibility for ensuring necessary amendments to the Commission's proposals for EU positions in trade agreements. Like other Council Advisory Committees, the 133 Committee has no formal operational guidelines. The Committee works by consensus and 'gentleman's agreement'; there are almost no formal votes - as one 133 Committee member stated: "we hardly ever vote". WORLD WIDE FUND FOR NATURE. A league of gentlemen: who really runs EU trade decision-making? nov. 2003. Disponível em: http:/ / www.google.com.br/url? sa $=\mathrm{t} \& \mathrm{rct}=\mathrm{j} \& \mathrm{q}=\& \mathrm{esrc}=\mathrm{s} \&$ sou $\mathrm{rce}=$ web\&cd=1\&ved=0CC8QFjAA Acesso em: 6 mar. 2018. p. 9.

73 Também a este respeito, Anna Murphy observa: "As a result, the 113 Committee's formal role remains advisory. On the other hand, as policy has been channelled through representatives of the Member States in the Committee, opinions of the 113 Committee are rarely overturned by the Council and are sometimes treated as if they were official decisions of the Council. Although it does not formally vote and Council decisions are taken on the basis of qualified majority, the Committee seeks consensus amongst the members. At a minimum, it tried to ensure that there is no blocking minority before passing matters upwards to the next level of decision-making. Conscious efforts are made not to ignore or isolate individual Member States". MURPHY, Anna. In the maelstrom of change: the article 113 committee in the governance of external economic policy. In: CHRISTIANSEN, Thomas; KIRCHNER, Emil. (eds.) Committee Governance in the European Union. Manchester: Manchester University Press, 2000. p. 98-104. p. 99.

74 Assim explicita Rafael Leal-Arcas: "The three main tasks of the Article 133 Committee are: 1) to advise the Commission in the negotiations on trade and tariff matters, which the Commission conducts on behalf of the Community; 2) to act as a typical Council preparatory body when preparing certain legislation for adoption by the EU Council; and 3) to advise the Commission on routine matters on which the Commission makes decisions vis-à-vis third countries in the management of the EC's common commercial policy." LEAL-ARCAS, Rafael. The EU institutions and their modus operandi in the world trading system. Columbia Journal of European Law, v. 12, p. 147-238, 2005. p. 161.

75 Por sua relevância no descortinamento deste assunto, nos referimos novamente ao relatório da World Wide Fund For Nature: "Like other Council Advisory Committee meetings, this Committee operates in camera normally without public agendas. However, the role of other Committees is balanced by a wider consultation process, which includes the European Parliament from the start. There are some significant differences in the discussions of the 133 Committee on international trade agreements which increase the impact of its secretive operations, compared with discussions of Council Committees in other policy areas: - It is the sole body consulted on proposed EU positions for trade agreements; Parliament is excluded from the consultation process. $\bullet$ It debates an unpublished Commission proposal. - It is strongly infuenced by expert and highly experienced Commission officials - in the words of one national expert: "it's the one committee where a very vocal and active Commission has the lead role, not governments". - It holds substantial decision-making powers in itself, particularly on the EU negotiating mandate, as national Trade Ministers do not often get involved in the technical details." WORLD WIDE FUND FOR NATURE. A league of gentlemen: who really runs EU trade decision-making? nov. 2003. Disponível em: http://www.google.com. $\mathrm{br} / \mathrm{url}$ ? $\mathrm{sa}=\mathrm{t} \& \mathrm{rct}=\mathrm{j} \& \mathrm{q}=\&$ esrc $=\mathrm{s} \&$ source $={ }_{\mathrm{web}} \& \mathrm{~cd}=1 \& \mathrm{ved}=0 \mathrm{CC} 8$ QFjAA Acesso em: 6 mar. 2018. p. 8-9.

76 "The 113 Committee lacks openness and transparency concerning its work." MURPHY, Anna. In the maelstrom of change: the article 113 committee in the governance of external economic policy. In: CHRISTIANSEN, Thomas; KIRCHNER, Emil. (eds.) Committee Governance in the European Union. Manchester: Manchester University Press, 2000. p. 98-104. p. 99. limitação imprecisa, uma vez que poucas informações oficiais estão disponíveis sobre esse tema.

Embora a transparência seja um dos princípios norteadores da atuação interna das instituições comunitárias, haveria uma mitigação desse princípio no que tange ao processo decisório relacionado ao Sistema de Solução de Controvérsias da OMC, uma vez que as reuniões e documentos dos órgãos internos da Comissão que compõem a tomada de decisão nessa matéria não estão disponíveis ao acesso do público. ${ }^{77}$

Alega-se que, dado o caráter técnico e estratégico da matéria, o incremento de transparência, accountability e legitimidade seria contraproducente e poderia afetar a agilidade com que as posições devem ser tomadas, podendo, inclusive, "ameaçar" a posição da UE no Sistema de Solução de Controvérsias da OMC. De todo modo, o procedimento previsto pelo regulamento das barreiras ao comércio oferece um relevante canal para participação dos setores interessados. ${ }^{78}$

Como se mencionou, recentes modificações nas competências das instituições comunitárias trazidas pelo Tratado de Lisboa permitem a participação do Parlamento Europeu na tomada de decisão em assuntos relativos à $\mathrm{OMC}$, o que, certamente, pode ser interpretado como uma tentativa de incremento na transparência, accountability e legitimidade nas negociações comerciais, ainda que com o custo de delongá-las e com o risco de afetar sua eficiência e sua flexibilidade. ${ }^{79}$

Cabe lembrar que já houve proposta do parlamento da UE para a constituição de um órgão de caráter parlamentar na OMC, ${ }^{80}$ objetivando um controle mais efeti-

77 SERDAREVIC, Asja. European Union and its member states as a collective actor in WTO decision-making process. ACES Cases, n. 2010.3. Disponível em: http://aei.pitt.edu/59173/1/ACES_Case_Serdarevic_2010.pdf. Acesso em: 05 mar. 2018. p. 17.

78 SERDAREVIC, Asja. European Union and its member states as a collective actor in WTO decision-making process. ACES Cases, n. 2010.3. Disponível em: http://aei.pitt.edu/59173/1/ACES_Case_Serdarevic_2010.pdf. Acesso em: 05 mar. 2018. p. 27.

79 "The implementation of trade policy stays with the Commission, but the Council and the EP will have some say in these matters. It is yet to be seen how the EP will use its legislative powers in trade policy to influence implementation." SERDAREVIC, Asja. European Union and its member states as a collective actor in WTO decision-making process. ACES Cases, n. 2010.3. Disponível em: http://aei.pitt.edu/59173/1/ACES_Case_Serdarevic_2010.pdf. Acesso em: 05 mar. 2018. p. 28.

80 Assim narra a autora: "[....] In November 1999, it [European Parliament] bad adopted a resoltution calling on 'the Council and the Commission to examine the possibility of setting up a WTO Parliamentary Assembly to achieve greater democratic accountability'. The proposal was then taken up and unanimously approved by the parliamentarians from WTO Member states at 
vo das atividades normativas da OMC, tendo em vista a percepção de que, nessa temática, há “[...] 'assimetrias de informação' e desconfiança democrática em face da construção intergovernamental de regras em instituições em todo o mundo, longe de cidadãos nacionais e grupos parlamentares." ${ }^{81}$

Por fim, retomando a temática da implementação das decisões do Sistema de Solução de Controvérsias da OMC pela União Europeia, explicite-se o pertinente diagnóstico de Antonello Tancredi:

Esta visão sumária mostra que o registro de
implementação da CE, embora não seja exemplar,
não se vincula a uma abordagem de não-
cumprimento em geral. Na maioria dos casos, de
fato, a Comunidade manifestou a sua vontade de
cumprir as decisões do OSC, tendo adotado as
medidas de aplicação, embora com atrasos muito
longos (medidas adotadas após o termo do período
de tempo razoável), e não sem contestação quanto à
sua coerência com a decisão desfavorável. Por outro
lado, os registros parecem refletir uma atitude que,
de acordo com a visão tradicionalmente mantida
pelo Tribunal de Justiça Europeu (TJE) desde o caso
International Fruit até o caso Portugal, encontra o
seu fundamento no princípio das negociações com
vistas a alcançar soluções mutuamente satisfatórias,
mesmo para além dos limites estabelecidos
pelo ESC. O número de litígios resolvidos pela
Comunidade, por si só ou em conjunto com os
seus Estados-Membros, por meio de uma solução
mutuamente acordada, apoia este ponto de vista.

the Seattle Ministerial, calling the 'establishment of a Standing Body of Parliamentarians whereby members of parliament can Exchange viens, be informed and monitor WTO negotiations and activities." MANN, Erika. A parliamentary dimension to the WTO: more than just a vision: reforming the World Trading System. In: PETERSMANN, Ernst-Ulrich. Reforming the World Trading System: legitimacy, efficiency and democratic governance. Oxford: Oxford University Press, 2005. p. 421-428. p. 424.

81 Tradução livre do original em língua inglesa: "[... "information asymmetries" and "democratic distrust" vis-à-vis intergovernmental rule-making in worldwide institutions far away from domestic citizens and parliamentary constituencies." PETERSMANN, Ernst-Ulrich. Multi-Level judicial trade governance without justice? on the role of domestic courts in the WTO Legal and Dispute Settlement System. EUI Working Paper $L A W$, n. 44, 2006. p. 19.

82 Tradução livre do original em língua inglesa: "This cursory overview shows that the EC's implementation record, though not exemplary, does not add up to a generally non-complying approach. In the majority of cases, in fact, the Community has declared its willingness to comply with the DSB's rulings, and has adopted implementation measures, albeit with exceedingly lengthy delays (measures adopted after the expiry of the reasonable period of time), and not without contestation as to their consistency with the adverse decision. On the other hand, the record seems to reflect an attitude that, in accordance with the view traditionally maintained by the European Court of Justice (ECJ) from International Fruit to Portugal, finds its cornerstone in the principle of negotiations with
No que se refere à aplicação de direitos oriundos de decisões do OSC, tais como a retaliação cruzada, é certo que a existência de competências compartilhadas entre a União e seus Estados membros torna ainda mais complexa a sua concretização, embora o TJUE/TJCE tenha estabelecido um dever de cooperação entre os Estados membros e a Comissão nessa matéria. ${ }^{83}$

Com a intenção de facilitar a aplicação de medidas retaliatórias devidamente autorizadas pelo OSC, foi aprovado em 2014 um regulamento que sistematiza a matéria, prevendo um procedimento único. Até então as medidas eram desenhadas caso a caso, por meio de propostas formuladas pela Comissão ao Conselho, que adotava as medidas apropriadas, como o Regulamento do Conselho n. 673/2005, relativo à controvérsia United States - Continued Dumping and Subsidy Offset Act of 2000 e o Regulamento do Conselho n. 728/2006, relativo ao caso United States - Tax Treatment for "Foreign Sales Corporations". ${ }^{84}$

Referido regulamento, aprovado pelo parlamento europeu em 2 de abril de $2014^{85}$ e adotado pelo Conselho

a view to achieving mutually satisfactory solutions, even beyond the limits set by the DSU. The number of disputes settled by the Community, alone or jointly with its Member States, by means of a mutually agreed solution, supports this view". TANCREDI, Antonello. EC Practice in the WTO: how wide is the 'scope for manoeuvre'? European Journal of International Law, v. 15, n. 5, p. 933-961, 2004. p. $936-937$.

83 MURPHY, Anna. In the maelstrom of change: the article 113 committee in the governance of external economic policy. In: CHRISTIANSEN, Thomas; KIRCHNER, Emil. (eds.) Committee Governance in the European Union. Manchester: Manchester University Press, 2000. p. 98-104. p. 105.

84 Nos dados oficiais divulgados na página da UE, consta a explicação do motivo pelo qual até 2012, quando o Regulamento do procedimento foi enviado, não havia este procedimento unificado. "However, prior to the Treaty of Lisbon, the distinction between legislative and executive functions was not clearly defined and, therefore, the allocation of responsibilities to the EU institutions was not as balanced as today. Moreover, there was no single framework to refer to when the EU was called to take action to defend its trade rights and interests." Press Release. Proposal for new enforcement framework for international trade rules European Commission - MEMO/12/1006, 18 dez. 2012. Disponível em: http://europa.eu/rapid/press-release_MEMO-12-1006_en.htm Acesso em: 20 mar. 2018.

85 European Parliament legislative resolution of 2 April 2014 on the proposal for a regulation of the European Parliament and of the Council concerning the exercise of the Union's rights for the application and enforcement of international trade rules (COM(2012)0773 - C7-0415/2012 - 2012/0359(COD)). Disponível em: http:// www.europarl.europa.eu/sides/getDoc.do?pubRef=- / /EP// $\mathrm{TEXT}+\mathrm{TA}+\mathrm{P} 7-\mathrm{TA}-2014-0264+0+\mathrm{DOC}+\mathrm{XML}+\mathrm{V} 0 / /$ EN\&language $=E N \#$ top. Acesso em: 20 mar. 2018. 
em 7 de maio de $2014,{ }^{86}$ é aplicável não somente às situações nas quais o OSC autorizou a suspensão de concessões ou outras obrigações, como modo de induzir o cumprimento, mas também com o intuito da imposição de contramedidas, com base no artigo 8 do Acordo de Salvaguardas, e em casos de reequilíbrio de concessões, com base no artigo XXVIII do GATTT $1994 .{ }^{87}$ O documento estabelece alguns critérios nos quais a aplicação das medidas deve se embasar, ${ }^{88}$ reforçando a previsibilidade e a segurança jurídica em sua aplicação.

\section{Considerações Finais}

Enquanto entidade única na sociedade internacional, tendo em conta o avançado grau de institucionalização de seu processo de integração econômica, o status da

86 COUNCIL OF THE EUROPEAN UNION. (OR. en) 9433/14. Brussels, 7 May 2014. Disponível em: http://register. consilium.europa.eu/doc/srv?l=EN\&f=ST $\% 209433 \% 202014 \% 20$ INIT Acesso em: 20 mar. 2018.

87 "Article 3 Scope-This Regulation applies: (a) following the adjudication of trade disputes under the WTO Understanding on Rules and Procedures Governing the Settlement of Disputes (WTO Dispute Settlement Understanding), when the Union has been authorised to suspend concessions or other obligations under the multilateral and plurilateral agreements covered by the WTO Dispute Settlement Understanding; (b) following the adjudication of trade disputes under other international trade agreements, including regional or bilateral agreements, when the Union has the right to suspend concessions or other obligations under such agreements; (c) for the rebalancing of concessions or other obligations, to which the application of a safeguard measure by a third country may give right pursuant to Article 8 of the WTO Agreement on Safeguards, or to the provisions on safeguards included in other international trade agreements, including regional or bilateral agreements; (d) in cases of modification of concessions by a WTO member under Article XXV III of the GATT 1994, where no compensatory adjustments have been agreed." COUNCIL OF THE EUROPEAN UNION. (OR. en) 9433/14. Brussels, 7 May 2014. Disponível em: http://register.consilium.europa.eu/ $\mathrm{doc} / \mathrm{srv} ? \mathrm{l}=\mathrm{EN} \& \mathrm{f}=\mathrm{ST} \% 209433 \% 202014 \% 20 \mathrm{INIT}$ Acesso em: 20 mar. 2018.

88 "Article 4 Exercise of the Union's rights: [...] 3. Commercial policy measures referred to in paragraph 1 shall be determined on the basis of the following criteria, in light of available information and of the Union's general interest: (a) effectiveness of the measures in inducing compliance of third countries with international trade rules; (b) potential of the measures to provide relief to economic operators within the Union affected by third country measures; (c) availability of alternative sources of supply for the goods or services concerned, in order to avoid or minimise any negative impact on downstream industries, contracting authorities or entities, or final consumers within the Union; (d) avoidance of disproportionate administrative complexity and costs in the application of the measures; (e) any specific criteria that may be established in international trade agreements in connection with the cases referred to in Article 3." COUNCIL OF THE EUROPEAN UNION. (OR. en) 9433/14. Brussels, 7 May 2014. Disponível em: http://register.consilium.europa.eu/ $\mathrm{doc} / \mathrm{srv} ? \mathrm{l}=\mathrm{EN} \& \mathrm{f}=\mathrm{ST} \% 209433 \% 202014 \% 20 \mathrm{INIT}$ Acesso em: 20 mar. 2018.
União Europeia como membro da OMC e, consequentemente, no Sistema de Solução de Controvérsias da OMC, abarca uma série de peculiaridades decorrentes de sua natureza jurídica não-estatal.

Coube ao órgão jurisdicional da UE a definição dos limites entre as competências da União e dos Estados membros na participação na OMC, cujas decisões são analisadas pela doutrina como profundamente impregnadas de pragmatismo e preocupações de natureza política, deixando de lado institutos até então consagrados no direito comunitário.

Embora tenha declarado a necessidade de comprometimento em conjunto pelos Estados membros em prol da Comunidade, quando da criação da OMC, o Tribunal furtou-se de esclarecer com precisão a relação entre a UE os Estados membros nessa matéria e a gestão prática da participação dos Estados membros na $\mathrm{OMC}$ e, em seu sistema de solução de controvérsias, tem cabido aos órgãos comunitários.

O TJUE reforçou a não aplicabilidade direta do Direito da OMC no ordenamento comunitário, o que não impediu que parte da doutrina vislumbrasse possibilidades do reconhecimento de uma obrigação da UE consubstanciada nos relatórios adotados pelo OSC, e uma consequente responsabilidade no caso de não implementação das decisões do Sistema de Solução de Controvérsias da OMC.

A posição de não aplicabilidade direta das regras dos Acordos multilaterais e das decisões do Sistema de Solução de Controvérsias da OMC - respectivamente, normas primárias e normas secundárias do Direito da OMC — parece consagrar uma posição pragmática do Tribunal, tendo em vista uma indesejabilidade do reconhecimento destas decisões como vinculantes às instituições comunitárias, como espécie de proteção de sua ordem comunitária em face de intervenções externas.

Por fim, destaca-se que, embora a própria operacionalização da participação da UE na OMC seja temática complexa e com certa obscuridade, as instituições comunitárias têm buscado incrementar a transparência, accountability e legitimidade dessa participação, inclusive a partir da criação de um regulamento sistematizando alguns procedimentos para a participação no Sistema de Solução de Controvérsias da OMC pela União Europeia. 


\section{REFERÊNCIAS}

ALEMANNO, Alberto. Judicial enforcement of the WTO hormones ruling within the european community: toward ec liability for the non-implementation of WTO Dispute Settlement Decisions. Harvard International Law Journal, v. 45, p. 547-562, 2004.

ANTONIADIS, Antonis. The European Union and WTO law: a nexus of reactive, coactive and proactive approaches. World Trade Review, v. 6, n. 1, p. 45-87, 2007.

BADIN, Michelle Ratton Sanchez; MOROSINI, Fabio Costa; OLIVEIRA, Inaê Siqueira de. Direito internacional econômico no Brasil: quem somos e o que fazemos?: evidências empíricas de 1994 a 2014. Revista de Direito Internacional, Brasília, v. 13, n. 1, p. 5-25, 2016.

BASTOS, Fernando Loureiro. Os acordos mistos em direito comunitário: contributo para a compreensão do seu fundamento jurídico. Lisboa: SPB II Editores, 1999.

BRAND, Ronald A. Direct effect of international economic law in the United States and the European Union. Northwestern Journal of International Law \& Business, v. 17, n. 1, p. 556-608, 1996-1997.

CAPUCIO, Camila. A natureza jurídica do Sistema de Solução de Controvérsias da OMC e de suas decisões: solucionando um imbróglio. Revista de Direito Internacional, Brasília, v. 14, n. 1, p. 315-340, 2017.

CAPUCIO, Camilla. A União Européia como sujeito de direito internacional: estudos sobre sua natureza jurídica e o Treaty Making Power Comunitário. Revista Eletrônica de Direito Internacional, v. 5, p. 34-68, 2009. Disponível em: http://www.cedin.com.br/revistaeletronica/volume5/. Acesso em: 20 ago. 2018.

CAPUCIO, Camilla. O regionalismo e o comércio internacional. 2. ed. Belo Horizonte: Arraes Editores, 2017.

CAPUCIO, Camilla. O status jurídico da União Européia como membro da OMC: estudo sobre os acordos mistos no direito comunitário. In: MENEZES, Wagner. Estudos de Direito Internacional. Curitiba: Juruá, 2009. p. 135-146.

COZENDEY, Carlos Márcio Bicalho. O Sistema de Solução de Controvérsias da OMC: para além dos contenciosos, a política externa. Disponível em: http://www. itamaraty.gov.br/temas/temas-multilaterais/copy_of_ desenvolvimento-comercio-e-financas/organizacaomundial-do-comercio/solucao-de-controversias/cgc/ artigo-cozendey. Acesso em: 15 dez. 2017.

DIZ, Jamile Bergamaschine Mata; JAEGER JÚNIOR, Augusto. Por uma teoria jurídica da integração regional: a inter-relação direito interno, direito internacional público e direito da integração. Revista de Direito Internacional, Brasília, v. 12, n. 2, p. 138-158, 2015.

EECKHOUT, Piet. Judicial enforcement of WTO Law in the European Union: some further reflections. Journal of International Economic Law, v. 5, p. 91-110, 2005.

EGLI, Patricia. European Community-EC compliance with rulings of WTO Dispute Settlement Body in Bananas dispute- effect of WTO agreements and dispute settlement rulings in EC law-standing to challenge EC legislation as inconsistent with WTO agreements and rulings. American Journal of International Law, v. 100, p. 449-454, 2006.

ERRICO, John. The WTO in the EU: Unwinding the Knot. Cornell International Law Journal, v. 44, p. 179-208, 2011.

GOMES, Eduardo Biachi. Integração econômica no MERCOSUL: opiniões consultivas e a democratização no acesso ao tribunal permante de revisão. Revista de Direito Internacional, Brasília, v. 10, n. 1, p. 128-136, 2013.

HELISKOSKI, Joni. Mixed agreements as a technique for organizing the international relations of the european community and its member states. Boston: Kluer Law International, 2001.

KUIJPER, Pieter J. The conclusion and implementation of the Uruguay Round Results by the European Community. European Journal of International Law, v. 6, p. 222-244, 1995.

LEAL-ARCAS, Rafael. Polycephalous anatomy of the EC in the WTO: an analysis of law and practice. Flórida Journal of International Law, v. 19, p. 569-670, 2007.

LEAL-ARCAS, Rafael. The EU institutions and their modus operandi in the world trading system. Columbia Journal of European Law, v. 12, p. 147-238, 2005.

MANN, Erika. A parliamentary dimension to the WTO: more than just a vision: reforming the World Trading System. In: PETERSMANN, Ernst-Ulrich. Reforming the World Trading System: legitimacy, efficiency and democratic governance. Oxford: Oxford University Press, 2005. p. 421-428.

MENGOZZI, Paolo. Istituzione di Diritto Comunitario e 
Dell $\square$ Unione Europea. Padova: CEDAM, 2003.

MEY, Delphine de. The effect of WTO Dispute Settlement Rulings in the EC Legal Order: Reviewing Van Parys v Belgische Interventie-en Restitutiebureau (C377/02). German Law Journal, v. 6, p. 1025-1032, 2005.

MURPHY, Anna. In the maelstrom of change: the article 113 committee in the governance of external economic policy. In: CHRISTIANSEN, Thomas; KIRCHNER, Emil. (eds.) Committee Governance in the European Union. Manchester: Manchester University Press, 2000. p. 98-104.

PETERSMANN, Ernst-Ulrich. From the hobbesian international law of coexistence to modern integration law: the W'TO Dispute Settlement System. Journal of International Economic Law, v. 1, n. 2, p. 175-198, 1998.

PETERSMANN, Ernst-Ulrich. How to constitutionalize international law and foreign policy for the benefit of civil society? Michigan Journal of International Law, v. 20, p. 1-30, 1998.

PETERSMANN, Ernst-Ulrich. Human rights, international economic law and constitutional justice: a rejoinder. European Journal of International Law, v. 19, n. 5, p. 955-960, 2008.

PETERSMANN, Ernst-Ulrich. Multilevel governance problems of the world trading system beyond the WTO Conference at Bali 2013. Journal of International Economic Law, v. 17, p. 233-270, 2014.

PETERSMANN, Ernst-Ulrich. Multilevel judicial governance as guardian of the constitutional unity of international economic law. Loyola of Los Angeles International and Comparative Law Review, v. 30, n. 3, p. 367-418, 2008.

PETERSMANN, Ernst-Ulrich. Multi-Level judicial trade governance without justice? on the role of domestic courts in the WTO Legal and Dispute Settlement System. EUI Working Paper LAW, n. 44, 2006.

POLLACK, Mark A. The new, new sovereigntism or how the Europe Union became disenchanted with international law and defiantly protective of its domestic legal order. 2017. Disponível em: http://dx.doi.org/10.2139/ssm.2956738. Acesso em: 09 set. 2018.

ROSAS, Allan. Implementation and enforcement of WTO dispute settlement findings: an EU perspective. Journal of International Economic Law, v. 4, p. 131-144, 2001.
SERDAREVIC, Asja. European Union and its member states as a collective actor in WTO decision-making process. ACES Cases, n. 2010.3. Disponível em: http://aei. pitt.edu/59173/1/ACES_Case_Serdarevic_2010.pdf. Acesso em: 05 mar. 2018.

SHAFFER, Gregory C. Is the EC moving towards a U.S. Partnership Model? In: SHAFFER, Gregory C. Defending interests: public-private partnerships in WTO litigation. Washington: Brooking Institutions Press, 2003. p. $65-101$.

STEINBERGER, Eva. The WTO treaty as a mixed agreement: problems with the EC's and the EC member states' membership of the WTO. European Journal of International Law, v. 17, n. 4, p. 837-862, 2006.

TANCREDI, Antonello. EC Practice in the WTO: how wide is the 'scope for manoeuvre'? European Journal of International Law, v. 15, n. 5, p. 933-961, 2004.

TJUE/TJCE. 94/800/EC: Council Decision (of 22 December 1994) concerning the conclusion on behalf of the European Community, as regards matters within its competence, of the agreements reached in the Uruguay Round multilateral negotiations (1986-1994), OJ L 336, 23.12.1994.

TJUE/TJCE. Amministrazione delle finanze dello Stato $v$. SPI and SAMI (Rec.1983, p. 801), Case 267/81, 16 mar. 1983.

TJUE/TJCE. Bresciani v. Amministrazione delle finanze dello Stato (Rec.1976, p.129), Case 87/75, 5 fev. 1976.

TJUE/TJCE. Chiquita Brands International, Inc. and Others v. Commission (Rec.2005, p. 11-315), Case T-19/01, 3 fev. 2005.

TJUE/TJCE. Commission of the European Communities, Proposal for a Council Decision Concerning the Conclusion of the Uruguay Round of Multilateral Trade Negotiations (198694) $\operatorname{Com}(94), 143$ apr. 15, 1994.

TJUE/TJCE. Demirel v. Stadt Schwäbisch Gmünd (Rec.1987, p.3719), Case 12/86, 30 out. 1987.

TJUE/TJCE. Fabbrica Italiana Accumulatori Motocarri Montecchio SpA v. Council (Rec.2008, p. 1-6513, 23-24, 30), Joined Cases C-120/06P \& C-121/06P, 9 set. 2008. TJUE/TJCE. Fédération de l'industrie de l'builerie de la CEE (Fediol) v. Commission (Rec.1989, p. 1-1781), Case C-70/87, 22 jun. 1989.

TJUE/TJCE. Germany v. Council (Rec.1994, p.I-4973), 
Case 280/93, 5 out. 1994.

TJUE/TJCE. Haegemann v. Belgian State (Rec.1974, p.449), Case 181/73, 30 abr. 1974.

TJUE/TJCE. International Fruit Company and others v. Produk.tschap voor Groenten en Fruit (Rec.1972, p.1219), Case 21/72, 12 dez. 1972.

TJUE/TJCE. Lon Van Parys NV v. Belgisch Interventieen Restitutieburean (BIRB) (Rec. 2005, p. 1-1465), Case C-377/02, 1 mar. 2005.

TJUE/TJCE. Itablissements Biret et Cie SA v. Council (Rec.2003, p. I-10565), Case C-94/02, 30 set. 2003.

TJUE/TJCE. Nakajima All Precision Co. Ltd v. Council (Rec.1991, p. 1-2069), Case C-69/89, 7 maio 1991.

TJUE/TJCE. Opinion 1/91, Draft agreement relating to the creation of the European Economic Area (Rec. 1991, p. 1-6079), 14 dez. 1991. para. 39-40.

TJUE/TJCE. Opinion 1/94 (Rec.1994, p.I-5267), 15 nov. 1994.

TJUE/TJCE. Opinion of Mr Advocate General Mischo delivered on 6 May 1999. Atlanta AG and others v Commission of the European Communities and Council of the European Union (Rec.1999, p.I-06983), Case C-104/97, 14 out. 1999.

TJUE/TJCE. Portugal v. Council (Rec.1999, p.I-8395), Case C-149/96, 23 nov. 1999.

TJUE/TJCE. Schlüter v. Hauptrollamt Lörrach (Rec.1973, p.1135), Case 9/73, 24 out. 1973.
TJUE/TJCE. SIOT v. Ministero delle finanze (Rec.1983, p.731), Case 266/81, 16 mar. 1983.

TRACHTMAN, Joel P. Bananas, direct effect and compliance. European Journal of International Law, v. 10, n. 4, p. $655-678,1999$.

WORLD TRADE ORGANIZATION. Apellate body report, european communities: customs classification of certain computer equipment. WT/DS62/AB/R, WT/ DS67/AB/R, WT'DS68/AB/R, 05 jun. 1998.

WORLD WIDE FUND FOR NATURE. A league of gentlemen: who really runs EU trade decision-making? nov. 2003. Disponível em: http://www.google.com.br/ url? $\mathrm{sa}=\mathrm{t} \& \mathrm{rct}=\mathrm{j} \& \mathrm{q}=\&$ esrc $=\mathrm{s} \&$ source $=$ web\& $\mathrm{cd}=1 \& \mathrm{ve}$ d=0CC8QFjAA . Acesso em: 6 mar. 2018.

ZONNEKEYN, Geert A. EC Liability for the NonImplementation of WTO Dispute Settlement Decisions - Advocate General Alber Proposes a 'Copernican Innovation' in the Case Law of the ECJ. Journal of International Economic Law, v. 6, p. 761-769, 2003.

ZONNEKEYN, Geert A. The latest on indirect efect of WTO Law in the legal order: the Nakajima case law misjudged? Journal of International Economic Law, p. 597608, 2001.

ZONNEKEYN, Geert A. The legal status of WTO panel reports in the EC legal order: Some reflections on the opinion of advocate general Mischo in the Atlanta case. Journal of International Economic Law, v. 2, p. 713$722,1999$. 
Para publicar na Revista de Direito Internacional, acesse o endereço eletrônico www.rdi.uniceub.br ou www.brazilianjournal.org.

Observe as normas de publicação, para facilitar e agilizar o trabalho de edição. 